\title{
Juvenile fish densities in Florida Keys mangroves correlate with landscape characteristics
}

\author{
C. Ashton Drew ${ }^{1, *}$, David B. Eggleston ${ }^{2}$ \\ ${ }^{1}$ Department of Zoology, North Carolina State University, 127 David Clark Labs, Raleigh, North Carolina 27695-7617, USA \\ ${ }^{2}$ Department of Marine, Earth, and Atmospheric Sciences, North Carolina State University, 2800 Faucette Drive, \\ Room 1125 Jordan Hall, Raleigh, North Carolina 27695-8208, USA
}

\begin{abstract}
Ecological patterns and processes are often scale-dependent. Understanding organisms' perceptions of and responses to landscape heterogeneity and connectivity is essential for effective conservation and management. We used multiple regression models with backward elimination to test relationships between juvenile fish density and diversity, quantified visually by snorkelers, and site$(100 \mathrm{~s} \mathrm{~m})$ and landscape-scale $(1 \mathrm{~km})$ habitat characteristics of mangroves in the Great White Heron National Wildlife Refuge (GWHNWR) in the lower Florida Keys, USA. We compared site and landscape model performance using Akaike's information criterion (AIC) and adjusted $\mathrm{R}^{2}$ values. Our results demonstrate the following: (1) juvenile fish density in mangrove backreef habitats correlated with landscape characteristics; (2) relationships between fish density and site or landscape characteristics differed greatly among species; and (3) juvenile fish diversity was not strongly correlated to either site or landscape characteristics. We therefore advise caution when (1) selecting fish species and sites for experiments to test nursery habitat hypotheses given the scale- and species-specific relationships between fish and mangrove habitats observed in the present study, and (2) implementing conservation strategies based upon habitat surrogates or quotas (e.g. protect $20 \%$ of mangrove habitat to conserve fish species) because landscape context might strongly, and uniquely, influence individual fish species' juvenile density. In light of our results, we argue in support of landscape analyses and individual-based modeling as useful tools to prioritize conservation of backreef nursery habitats.
\end{abstract}

KEY WORDS: Backreef habitats $\cdot$ Nursery role $\cdot$ Habitat quality $\cdot$ Spatial scale $\cdot$ Conservation $\cdot$ Coral reef fish · Landscape ecology

\section{INTRODUCTION}

Understanding organisms' perceptions of and responses to landscape heterogeneity and connectivity is essential for effective ecological conservation and management (Doak \& Mills 1994, Poiani et al. 2000, Collinge 2001). The need for such understanding is particularly urgent in marine environments given present initiatives to identify and conserve nearshore estuarine and marine ecosystems that serve as nursery habitats (sensu Beck et al. 2001) for many marine fish and invertebrate species. Nursery habitats support higher density, productivity or survivorship of juvenile stages than surrounding alternative habitat types or simply offer greater connectivity to adult habitats and thereby support higher successful export of individuals to adult habitat (Beck et al. 2001). Significant effort has been applied towards clarifying the functional definition of nursery habitat and developing hypothesisdriven criteria for delineating these sites (Beck et al. 2001). Empirical studies have shifted focus from simply demonstrating the presence of fish or invertebrate juveniles within nursery habitats to investigating the relative value of different nursery habitats (Dahlgren \& Eggleston 2001) and studying linkages between nursery and adult populations (Cocheret de la Morinière et al. 2002, Gillanders et al. 2003, Sheaves 2005). These papers demonstrate that (1) better growth and survival do occur in some nearshore habitats than in others, and (2) adult fish density does sometimes correlate posi- 
tively with the neighboring presence (versus absence) of presumed nursery habitat. These studies, however, focus largely on microhabitat characteristics within coarsely defined habitat types (e.g. mangroves, seagrass and estuaries) and do not explicitly consider the effects of landscape composition, configuration and connectivity on organism distribution and abundance patterns among patches of the same habitat type.

There are scale-dependent ecological patterns and processes that vary between terrestrial and marine systems, as well as among species within marine systems. For example, terrestrial species-area relationships predict greater species diversity in larger patches, whereas several marine studies have found that smaller patches appear to attract more immigrants, support higher survival rates, and have greater species diversity than large patches (Eggleston et al. 1998, 1999, Hovel \& Lipcius 2002). Species-area curves also appear steeper for marine species than for their terrestrial counterparts (Chittaro 2002). In a mangrove and coral reef system in the Virgin Islands, Caribbean Sea, with the exception of one unfished species of fish Gerres cinereus, there was generally no relationship between adult coral reef fish densities, the size of mangrove nursery habitat, and proximity of mangrove patches (Halpern 2004). Conversely, Mumby et al. (2004) and Nagelkerken et al. (2002) found positive and scale-dependent relationships between adult fish population density and nursery habitat in other locations within the Caribbean Sea. Mangrove prop-roots are an important backreef habitat for many species of coral reef fish; however, there is a large degree of uncertainty regarding the role of site versus landscape characteristics on variation in reef fish distribution and abundance patterns and diversity (see review by Faunce \& Serafy 2006). Adult population response to nursery habitat patch size and isolation is a key component of the nursery habitat definition, yet no consistent pattern has emerged to identify the scale at which patch size and isolation (or other landscape pattern metrics) have the greatest influence on fish populations. This ambiguity may reflect the diverse spatial scales of the published studies, the presence of species-specific scaling of responses to landscape patterns and geographic variation in species dependence on nursery habitat.

The present study examined the relationships between juvenile fish population density and diversity and mangrove habitat characteristics in the Florida Keys, USA. Fish population density and diversity and habitat features at 31 mangrove sites in the Great White Heron National Wildlife Refuge (GWHNWR) were previously quantified using visual surveys (Eggleston et al. 2004a). These data revealed significant variation in fish species diversity, overall fish pop- ulation density, and population density of individual fish species among mangrove stations (Eggleston et al. 2004a). They did not, however, find a relationship between total fish population density or diversity and site features (water depth, distance visible into mangrove prop-roots, and mangrove canopy height). The present study was initiated to determine if landscape characteristics could explain observed variation in fish species density and diversity among the mangrove stations sampled in Eggleston et al. (2004a). Our approach is novel in that, rather than focusing solely on the ecology of the life stage found in mangrove habitat and the characteristics of the immediate mangrove microhabitats, we incorporated independent variables that (1) reflected the highly mobile and complex life history of each individual species, and (2) considered both the site (measured in situ over 100s meters) and landscape (measured remotely over 1 to $10 \mathrm{~s} \mathrm{~km}$ ) characteristics of mangrove habitat patches.

We hypothesized that the relative nursery quality of 2 mangrove patches selected for study or conservation might not simply reflect microhabitat characteristics at a given site (e.g. water depth), but also regional landscape context, such as proximity to oceanic larval sources for pelagic-spawned species or proportional cover of seagrass in neighboring waters for species that depend on this resource in earlier or later life stages. We asked the following: (1) Is there evidence that landscape characteristics influence juvenile fish density and diversity in mangrove patches; and (2) what is the relative weight of evidence for remotely-sensed landscape measurements versus rapid in situ site measurements as indicators of juvenile fish density and diversity? Our purpose in asking these questions was not to debate the importance of microhabitat characteristics on juvenile fish growth and survival. Rather, we wanted to investigate the potential for landscape data to inform our assessments of nursery habitat quantity and quality, especially in situations where mangrove patches may be remote, inaccessible or under imminent threat.

\section{MATERIALS AND METHODS}

Study site. The GWHNWR is part of a network of protected areas designed to conserve the ecological and economic resources of the Florida Keys ecosystem. The refuge, located on the north (Gulf of Mexico) side of the lower Florida Keys, extends west of Marathon Key from the middle of Seven Mile Bridge to the eastern end of Key West (Fig. 1). It was established in 1938 to protect migratory birds such as herons and egrets from commercial exploitation. Neither commercial nor recreational fishing is restricted within the park, except within certain vessel exclusion zones near impor- 


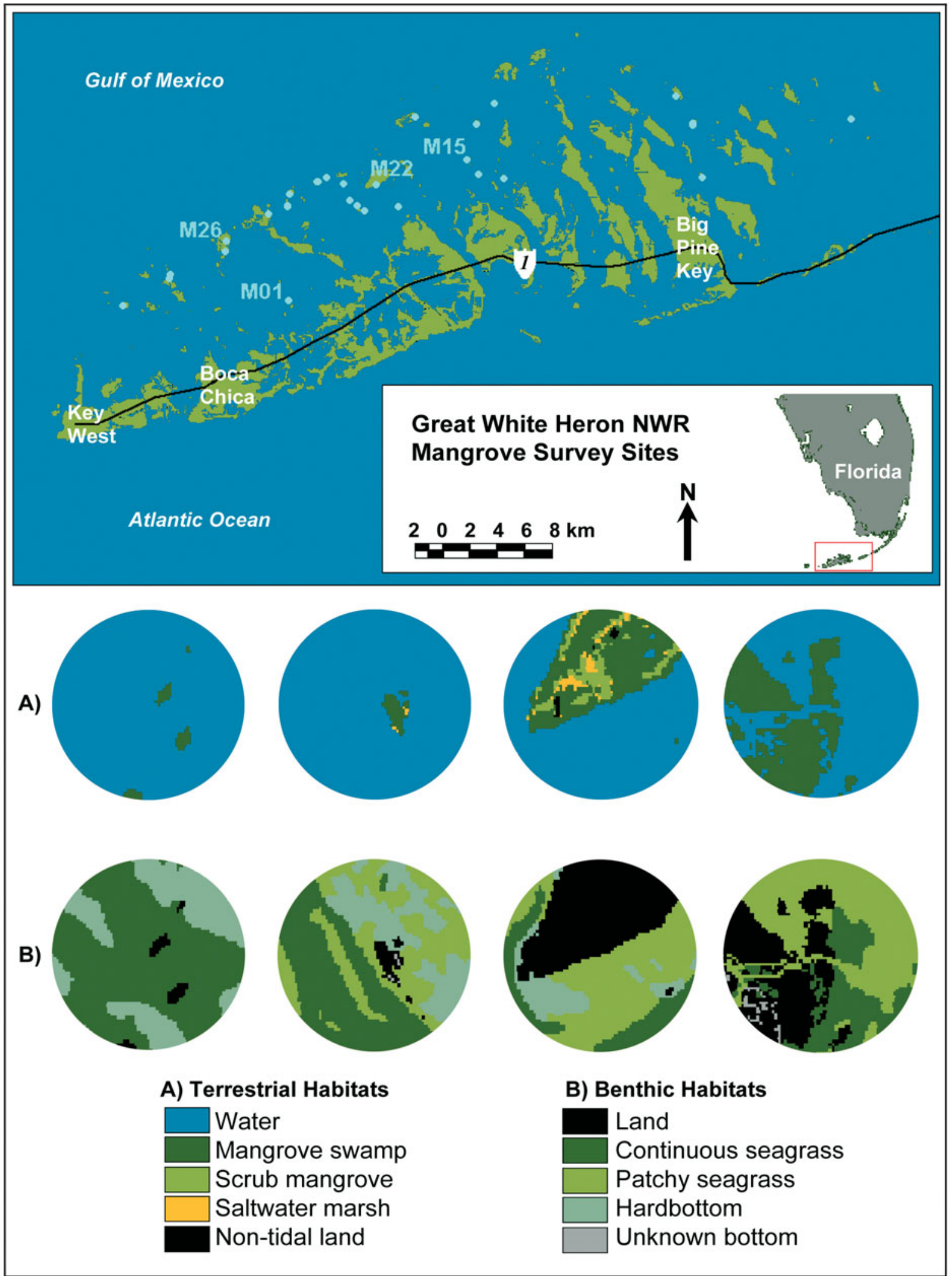

Fig. 1. Great White Heron National Wildlife Refuge (NWR) study area in Florida Keys, USA, showing mangrove survey sites as light blue dots (1: Highway 1). Examples of the diverse (A) terrestrial and (B) benthic habitats within $1 \mathrm{~km}$ radius buffers are shown for 4 stations 
tant colonial nesting sites (e.g. frigate birds Fregata sp.). Most of the refuge area $\left(\sim 784 \mathrm{~km}^{2}, 99 \%\right)$ is designated as intra- or subtidal wilderness marine habitat, including mangroves, seagrass beds, hardbottom, macroalgal beds, sand flats and coral reefs. The hydrography of the area is influenced both by the Gulf of Mexico and the Florida Current, and species composition in the area likely reflects recruitment from both water masses (Eggleston et al. 2004c).

Fish surveys and site habitat characteristics. In July to August 2002 and August 2003, Eggleston et al. (2004a) performed the first systematic survey of fish and backreef habitats across a mosaic of 5 habitat types within the GWHNWR. These surveys documented fish density, diversity, and size structure, as well as habitat characteristics, at 31 randomly selected mangrove island sites. The survey methods had been developed and tested in similar habitat elsewhere in the Florida Keys (Eggleston \& Dahlgren 2001, Eggleston et al. 2004b). Each island was surveyed once by multiple divers simultaneously, as near as possible to a daytime high tide, during $7 \mathrm{~d}$ bracketing the new moon in each month. Such timing reduced the influence of season, water depth (Sheridan \& Hays 2003) and diel, or lunar variation (Rooker \& Dennis 1991), on fish counts. Water visibility exceeded $10 \mathrm{~m}$ at all sites. GPS coordinates were obtained as close to the mangrove fringe as possible, central to the total length of mangrove coastline surveyed by all snorkelers.

At each island, 2 to 4 snorkelers performed nonoverlapping, 10 min visual surveys of fish populations and habitat characteristics within and alongside the mangrove prop-roots. The mean value of snorkelers' observations was used in statistical analyses. Snorkelers recorded individual fish by species and length to the nearest centimeter (except large schools of baitfish, which were estimated by 100 s or 1000 s), and then fish counts were standardized by area searched (fish per $100 \mathrm{~m}^{2}$ ). Snorkelers calculated their search area by measuring the survey distance and estimating the mean distance into the prop-root system through which they could reliably count fish (typically 2 to $4 \mathrm{~m}$, hereafter referred to as 'distance visible into proproots'). As prop-root density and fouling, not water clarity, primarily limited the distance visible into proproots at our survey sites, this distance measure also provided an indication of relative habitat complexity. Each snorkeler also recorded the water depth and canopy height (an allometric substitute for prop-root density, see Smith \& Whelan 2006) within their section. Of the 31 mangrove sites surveyed by Eggleston et al. (2004a), 22 were defined as spatially independent (sites separated by $>1 \mathrm{~km}$ ) at the $1 \mathrm{~km}$ regional scale used in our landscape analyses and therefore served as the sample units of the present study (Fig. 1).

Juvenile fish were identified based on maximum length data ( $\mathrm{cm}$ total length, TL) presented in the Life History Data Tool in FishBase (Froese \& Pauly 2000). All fish less than one-third of the maximum length were classified as juveniles; this method is reliable for several Caribbean mangrove and seagrass fish species (Nagelkerken \& van der Velde 2002, 2004). Our density analyses (no. ind. per $100 \mathrm{~m}^{2}$ ) included only species and families observed at 10 or more sites (Table 1).

Table 1. Great White Heron National Wildlife Refuge juvenile fish density and diversity data. Juvenile fish density values are presented for species or families present at 10 or more of 22 spatially independent mangrove sites (sites separated by at least $1 \mathrm{~km}$ ). Each species at each site was represented by one value: the mean density of juvenile fish per $100 \mathrm{~m}^{2}$ based on fish counts by multiple divers simultaneously deployed for $10 \mathrm{~min}$ at each site. Species in some families were grouped due to the difficulty of distinguishing juveniles of these species. Juvenile fish diversity values reflect all observed species, rare and common, and represent the mean from multiple surveys at each site. We report the average (Avg.), standard deviation (SD), minimum (Min.), and maximum (Max.) mean fish density and diversity. Note that mean fish density varies one or more orders of magnitude for all species and the SDs around the mean density are very high. ACE: Athernidae, Clupeidea, Engraulidae complex

\begin{tabular}{|c|c|c|c|c|c|c|}
\hline Juvenile fish & Common name & $\mathrm{N}$ & Avg. & SD & Min. & Max. \\
\hline \multicolumn{7}{|l|}{ Density (ind. per $100 \mathrm{~m}^{2}$ ) } \\
\hline Atherinidae & Silversides & 15 & 1043.5 & 1420.7 & 68.8 & 4761.9 \\
\hline Ablennes hians & Flat needlefish & 10 & 6.8 & 9.4 & 0.3 & 31.1 \\
\hline Anisotremus virginicus & Porkfish & 10 & 4.8 & 3.2 & 0.7 & 10.0 \\
\hline Archosargus rhomboidalis & Seabream & 11 & 6.5 & 5.9 & 0.6 & 16.3 \\
\hline Engraulidae & Anchovies & 15 & 1646.3 & 2016.8 & 26.7 & 5677.8 \\
\hline Gerreidae & Mojarras & 20 & 27.7 & 43.2 & 0.4 & 158.5 \\
\hline Lutjanus apodus & Schoolmaster & 14 & 2.2 & 3.5 & 0.2 & 13.7 \\
\hline Lutjanus griseus & Gray snapper & 22 & 84.8 & 103.1 & 5.9 & 421.2 \\
\hline Sphyraena barracuda & Great barracuda & 21 & 1.9 & 1.7 & 0.3 & 7.2 \\
\hline Total fish density (excludin & species) & 22 & 124.8 & 106.1 & 18.8 & 434.9 \\
\hline \multicolumn{7}{|l|}{ Diversity } \\
\hline Shannon evenness index & & 22 & 0.34 & 0.14 & 0.13 & 0.60 \\
\hline Rarefied species density & & 22 & 4.9 & 1.7 & 2.0 & 7.8 \\
\hline
\end{tabular}


The diversity analyses, Shannon's evenness index (Washington 1984) and rarefied species density were conducted using all observed juveniles. Rarefaction facilitates comparison of the number of species among samples with different numbers of individuals by standardizing against the sample with the fewest individuals (Sanders 1968, Gotelli \& Colwell 2001). In our case, where all counts of individuals had been standardized to the area searched, we rarefied to a common density of individuals to match the lowest observed density among mangrove sites (no. species per 150 ind. per $100 \mathrm{~m}^{2}$ ).

Landscape characteristics. We tested the relationships between juvenile fish density and diversity and characteristics of 3 landscapes: benthic, bathymetric and terrestrial. The Florida Keys Benthic Habitats (FKBH) atlas (Florida Marine Research Institute 1998) provided digital, shallow-water $(<2 \mathrm{~m})$ benthic cover data for 6 habitat types: continuous seagrass, patchy seagrass, patch reef, platform margin reef, hardbottom and barren. Areas deeper than $2 \mathrm{~m}$ were classified as ocean. Specific descriptions of each habitat type may be found in the FKBH metadata files (Florida Marine Research Institute 1998). This digital atlas also provided bathymetric data, which identified the major channels and the $10 \mathrm{~m}$ isobaths surrounding the GWHNWR. The Florida Vegetation and Land Cover (FVLC) atlas (Florida Fish and Wildlife Conservation Commission 2004) provided digital data characterizing 17 natural (e.g. forested) and semi-natural (e.g. golf course) terrestrial land cover types, 4 land cover types indicative of human disturbance, and 1 water class. We extracted the data for mangrove swamp, scrub mangrove, salt marsh, tidal flat, high-impact urban and low-impact urban classes and then combined all other vegetation and land cover classes into a single category: other non-tidal land. Specific descriptions of terrestrial habitat types may be found in the FVLC metadata files (Florida Fish and Wildlife Conservation Commission 2004).

In ArcView 3.2a GIS, we used PatchGrid Fragstats to calculate landscape metrics for the area within a $1 \mathrm{~km}$ radius of each site's central coordinates. We calculated number of habitat types, number of patches (sensu Watling \& Donnelly 2006: discrete habitat unit surrounded by distinct habitat from which it is easily distinguishable), mean patch size, and habitat diversity (Table 2). In addition, proportional cover of a given benthic (or terrestrial) habitat type was calculated both as the ratio between the area of the habitat type of interest and (1) the area of the entire $1 \mathrm{~km}$ radius buffer, and (2) the buffer region's total benthic (or terrestrial) habitat area. Finally, we measured the straight-line distance from the mangrove station to both the Gulf of Mexico and Atlantic Ocean $10 \mathrm{~m}$ isobaths, as well as to the nearest major channel (Table 2).

Statistical analyses. We tested the appropriateness of the data for assemblage-level statistics (e.g. ordination) and did not find the data compatible with these methods. We therefore chose to proceed by testing juvenile species-habitat correlations independently for each species.

We employed a series of backwards elimination, multiple regression models (SPSS 13.0; removal of independent variables at probability $F=0.10$ ) to measure correlations between fish density and diversity and mangrove habitat characteristics. The juvenile fish density data were log transformed due to the high variation (several orders of magnitude) in density among mangrove sites. The independent site and landscape variables were square root, log or arcsine transformed depending upon the shape of the raw data's distribu-

Table 2. Habitat data from 22 spatially independent mangrove sites (sites separated by at least $1 \mathrm{~km}$ ) within the Great White Heron National Wildlife Refuge. Patch data were quantified during field surveys (Eggleston et al. 2004a), and benthic, terrestrial, and bathymetric landscape data were taken from digital maps (see 'Materials and methods; Landscape characteristics' for details)

\begin{tabular}{|c|c|c|c|c|}
\hline & Avg. & $\mathrm{SD}$ & Min. & Max. \\
\hline \multicolumn{5}{|l|}{ Mangrove patches } \\
\hline Mean water depth (m) & 1.5 & 0.9 & 0.5 & 3.8 \\
\hline Mean canopy height (m) & 5.4 & 1.4 & 3.8 & 8.9 \\
\hline $\begin{array}{l}\text { Mean distance visible into } \\
\text { prop-roots }(\mathrm{m})\end{array}$ & 2.9 & 1.3 & 0.8 & 6.6 \\
\hline \multicolumn{5}{|l|}{ Benthic landscapes } \\
\hline Total seagrass area $\left(\mathrm{m}^{2}\right)$ & $2.21 \times 10^{6}$ & $6.96 \times 10^{5}$ & $6.49 \times 10^{5}$ & $3.11 \times 10^{6}$ \\
\hline Continuous seagrass area $\left(\mathrm{m}^{2}\right)$ & $1.49 \times 10^{6}$ & $8.98 \times 10^{5}$ & $1.26 \times 10^{5}$ & $2.77 \times 10^{6}$ \\
\hline Hardbottom area $\left(\mathrm{m}^{2}\right)$ & $6.29 \times 10^{5}$ & $7.52 \times 10^{5}$ & 0.00 & $2.41 \times 10^{6}$ \\
\hline Bare area $\left(\mathrm{m}^{2}\right)$ & $2.80 \times 10^{4}$ & $9.32 \times 10^{4}$ & 0.00 & $3.80 \times 10^{5}$ \\
\hline Shannon diversity index & 0.88 & 0.25 & 0.42 & 1.26 \\
\hline \multicolumn{5}{|l|}{ Terrestrial landscapes } \\
\hline Island perimeter/area ratio & 0.042 & 0.046 & 0.004 & 0.184 \\
\hline Swamp mangrove area $\left(\mathrm{m}^{2}\right)$ & $2.20 \times 10^{5}$ & $2.72 \times 10^{5}$ & $2.83 \times 10^{3}$ & $9.93 \times 10^{5}$ \\
\hline Marsh area $\left(\mathrm{m}^{2}\right)$ & $4.07 \times 10^{3}$ & $1.63 \times 10^{5}$ & 0.00 & $7.70 \times 10^{4}$ \\
\hline Number of mangrove patches & 0.82 & 3.42 & 0.00 & 16.00 \\
\hline \multicolumn{5}{|l|}{ Bathymetric landscapes } \\
\hline $\begin{array}{l}\text { Distance to nearest major } \\
\text { channel }(\mathrm{m})\end{array}$ & 1973 & 1499 & 100 & 5200 \\
\hline Distance to Gulf of Mexico (m) & 1673 & 6798 & 8200 & 34800 \\
\hline Distance to Atlantic Ocean (m) & 21877 & 3941 & 12400 & 28000 \\
\hline
\end{tabular}


tion (Legendre \& Legendre 1998). Following transformation, data points greater than 2 standard deviations from the mean were labeled as outliers and excluded from the analyses to meet assumptions of normality and homogeneity of variances associated with multiple regression models (McCune \& Grace 2002).

Each regression model included multiple site or landscape independent variables and one dependent variable (first with individual fish species' density, then with total juvenile fish density and diversity indices). Site models were always initiated with the 3 independent variables that had been measured in situ: water depth, mangrove canopy height, and distance visible into prop-roots. The landscape models were parameterized based upon complete life history habitat requirements (e.g. proportional cover of seagrass within $1 \mathrm{~km}$ was included for species known to inhabit or feed within seagrass during at least one life stage). An initial selection of potential parameters was based upon information from peer-reviewed literature, personal communications, unpublished field observations, and the FishBase database. Our regression models had low sample size (from 9 to 22 sites) because meeting the assumptions for parametric statistics required the removal of spatially overlapping sites and sites with zero counts of a given species, as well as the significant outlier sites. Given our low sample size, we were cautious not to overfit the models by including too many independent variables in the models (Legendre \& Legendre 1998). In some cases 2 or more independent variables deemed important were autocorrelated, such that only one could be included in a given model.

Akaike's information criterion (AIC) (Akaike 1973, Burnham \& Anderson 2002) can be used to calculate the relative weight of evidence for individual models within a set of competing models while accounting for differences in the number of model parameters. We used a procedure to adjust AIC values for small sample size (AICC) (Burnham \& Anderson 2002) and then calculated the AIC weights to identify the best-fitting landscape model for a given dependent variable and to compare the best-fitting site and landscape models. We also reported each model's adjusted $\mathrm{R}^{2}$ value to indicate the strength of the species-habitat correlations.

\section{RESULTS}

Of the greater than 280000 fish representing 45 species in 25 families observed in the GWHNWR mangroves, just over 200000 fish of 37 species in 20 families were identified as juveniles. Most of these juvenile fish $(97.2 \%)$ were from the families Atherinidae, Clupeidea, and Engraulidae (hereafter referred to as the
ACE complex), which swam in large schools along the mangrove fringe of some islands. The next most abundant species, Lutjanus griseus, accounted for $2 \%$ of total juvenile fish sightings or $64.7 \%$ of non-ACE complex juvenile fish sightings. Other species accounting for greater than $1 \%$ of the non-ACE juvenile species sightings were: Eucinostomus melanopterus (14.1\%), Archosargus rhomboidalis (3.1\%), Anisotremus virginicus $(2.7 \%)$, Gerres cinereus (2.6\%), Ablennes hians $(2.4 \%)$, Sphyraena barracuda $(2.3 \%)$, and Lutjanus apodus $(1.6 \%)$. Many juvenile species were present at only one mangrove site, and only 10 species or families were present at 10 or more of the 22 sites included in the present study.

\section{Juvenile fishes and mangrove site characteristics}

Juvenile fish population density among mangrove sites demonstrated weak to moderate correlation with the mangrove site characteristics water depth and distance visible into prop-roots (Table 3 ). The backwards elimination, multiple linear regression models were significant for 3 of the 9 juvenile fish species present at a minimum of 10 survey sites. Water depth was the only variable included in these reduced models, with the exception of the model for Lutjanus griseus, which included both water depth and the distance visible into prop-roots. Greater densities of juvenile Gerreidae and L. griseus were found at shallower sites, while juvenile Anisotremus virginicus density was positively associated with deeper water sites (Table 3). L. griseus juvenile densities were greatest at shallow mangrove sites where prop-root fouling and complexity limited the distance visible into prop-roots. Based upon the adjusted $\mathrm{R}^{2}$ values, site characteristics measured in situ, when significant, accounted for between $14.8 \%$ (L. griseus) and $46.2 \%$ (Gerreidae) of the observed variability in juvenile fish density. There was a weak negative relationship (adjusted $\mathrm{R}^{2}=0.169$ ) between the Shannon evenness index for juvenile fish and both canopy height and water depth at mangrove sites in the GWHNWR.

\section{Juvenile fish density and landscape characteristics}

The landscape models provided the best fit to the observed juvenile fish density data (higher AIC weight) for 5 of the 9 species groups (Table 3: Atherinidae, Engraulidae, Lutjanus griseus, Archosargus rhomboidalis and Sphyraena barracuda). Based on adjusted $\mathrm{R}^{2}$ values, landscape models explained $17.8 \%$ (Engraulidae) to $70.6 \%$ (A. rhomboidalis) of the observed variability in juvenile fish density among sites where these species were present. The reduced multi- 
Table 3. Results of multiple regression analyses to test the relationship between juvenile fish density and diversity and mangrove patch- and landscape-scale habitat characteristics in Great White Heron National Wildlife Refuge. Patch independent variables in the reduced regression models included: water depth (depth), canopy height (canopy), and distance visible into prop-roots (visible). Landscape independent variables included: proportion of benthic habitat within $1 \mathrm{~km}$ radius covered with continuous seagrass beds (cont. area), proportion of benthic habitat within $1 \mathrm{~km}$ radius covered with either patchy or continuous seagrass beds (seag. area), benthic habitat Shannon diversity within $1 \mathrm{~km}$ radius (benthic SDI), mangrove island perimeter/area ratio (island p/a), number of mangrove swamp patches within a $1 \mathrm{~km}$ radius (swamp no.), area of mangrove habitat within a $1 \mathrm{~km}$ radius (mang. area), distance to the Atlantic $10 \mathrm{~m}$ isobath (Atlantic), distance to the Gulf of Mexico $10 \mathrm{~m}$ isobath (gulf), and distance to the nearest major channel (channel). Variables entered into the model then removed during each step of the regression procedure are indicated by the notation: drop1, drop2, etc. See 'Materials and methods; Statistical analyses' for the criteria used to identify the most parsimonious regression model. Significance of regression beta coefficients noted with asterisks $\left({ }^{* * *}<0.001 ;\right.$ $\left.{ }^{* *}<0.01,{ }^{*}<0.1\right)$. na: not applicable. AIC: Akaikes information criterion; ACE: Athernidae, Clupeidea, Engraulidae complex

\begin{tabular}{|c|c|c|c|c|c|c|c|c|}
\hline Dependent variable & Patch model & $\mathrm{N}$ & Adj. $R^{2}$ & AIC weight & Landscape model & $\mathrm{N}$ & Adj. $\mathrm{R}^{2}$ & AIC weight \\
\hline \multicolumn{9}{|l|}{ Juvenile fish density } \\
\hline \multirow[t]{3}{*}{ Atherinidae (silversides) } & $\begin{array}{c}\text { No solution } \\
\text { Depth = drop1 }\end{array}$ & 15 & na & na & $\begin{array}{c}\text { Atlantic }=-0.491^{*} \\
\text { Benthic SDI }=-0.466^{*}\end{array}$ & 15 & 0.303 & 0.645 \\
\hline & Canopy = drop2 & & & & Island $\mathrm{p} / \mathrm{a}=$ drop 1 & & & \\
\hline & Visible = drop3 & & & & & & & \\
\hline \multirow{4}{*}{ Ablennes hians (needlefish) } & $\begin{array}{c}\text { No solution } \\
\text { Depth = drop1 }\end{array}$ & 10 & na & na & $\begin{array}{l}\text { No solution } \\
\text {. }\end{array}$ & 10 & na & na \\
\hline & Canopy = drop2 & & & & Atlantic = drop2 & & & \\
\hline & Visible $=$ drop3 & & & & $\begin{array}{l}\text { Swamp no. = drop3 } \\
\text { Channel = drop4 }\end{array}$ & & & \\
\hline & & & & & Island $\mathrm{p} / \mathrm{a}=$ drop5 & & & \\
\hline \multirow{4}{*}{$\begin{array}{l}\text { Anisotremus virginicus } \\
\text { (porkfish) }\end{array}$} & $\begin{array}{l}\text { Depth }=0.647^{*} \\
\text { Visible }=\text { drop1 }\end{array}$ & 10 & 0.347 & 0.673 & $\begin{array}{l}\text { No solution } \\
\text { Gulf = drop1 }\end{array}$ & 10 & na & na \\
\hline & Canopy $=$ drop 2 & & & & Island $\mathrm{p} / \mathrm{a}=$ drop 2 & & & \\
\hline & & & & & Channel = drop3 & & & \\
\hline & & & & & Hardbottom = drop 4 & & & \\
\hline \multirow{3}{*}{$\begin{array}{l}\text { Archosargus rhom- } \\
\text { boidalis (seabream) }\end{array}$} & No solution & 11 & na & na & Cont. area $=0.545^{*}$ & 11 & 0.706 & 0.724 \\
\hline & $\begin{array}{l}\text { Deptn = drop } 1 \\
\text { Canopy = drop } 2\end{array}$ & & & & $\begin{aligned} \text { Swamp no. } & =0.625^{*} \\
\text { Benthic SDI } & =-0.643^{*}\end{aligned}$ & & & \\
\hline & Visible $=$ drop3 & & & & Island $\mathrm{p} / \mathrm{a}=$ drop 1 & & & \\
\hline \multirow[t]{4}{*}{ Engraulidae (anchovies) } & No solution & 15 & na & na & Gulf $=0.487^{*}$ & 15 & 0.178 & 0.436 \\
\hline & Canopy = drop1 & & & & Channel = drop1 & & & \\
\hline & Visible $=$ drop 2 & & & & Mang. area = drop2 & & & \\
\hline & Depth $=$ drop3 & & & & Benthic SDI = drop3 & & & \\
\hline \multirow[t]{3}{*}{ Gerreidae (mojarra) } & $\begin{array}{l}\text { Depth }=-0.700^{* * *} \\
\text { Visible }=\text { drop1 }\end{array}$ & 20 & 0.462 & 0.615 & $\begin{array}{c}\text { Swamp no. }=-0.570^{* *} \\
\text { Channel }=-0.323^{*}\end{array}$ & 20 & 0.401 & 0.077 \\
\hline & Canopy = drop2 & & & & Mang. area = drop1 & & & \\
\hline & & & & & $\begin{array}{l}\text { Island p/a = drop2 } \\
\text { Atlantic = drop3 }\end{array}$ & & & \\
\hline \multirow{5}{*}{$\begin{array}{l}\text { Lutjanus apodus } \\
\text { (schoolmaster) }\end{array}$} & No solution & 13 & na & na & No solution & 13 & na & na \\
\hline & Depth = drop1 & & & & Channel $=$ drop 1 & & & \\
\hline & Visible $=$ drop2 & & & & Atlantic $=$ drop2 & & & \\
\hline & Canopy = drop3 & & & & Swamp no. = drop3 & & & \\
\hline & & & & & $\begin{array}{l}\text { Island } \mathrm{p} / \mathrm{a}=\text { drop } 4 \\
\text { Bentbic } \mathrm{SDI}=\text { drop } 5\end{array}$ & & & \\
\hline \multirow{3}{*}{$\begin{array}{l}\text { Lutjanus griseus } \\
\text { (gray snapper) }\end{array}$} & Depth $=-0.392^{*}$ & 22 & 0.148 & 0.000 & Gulf $=-0.236^{*}$ & 22 & 0.560 & 0.309 \\
\hline & Visible $=-0.495^{*}$ & & & & Island $\mathrm{p} / \mathrm{a}=0.521^{* * *}$ & & & \\
\hline & Canopy = drop1 & & & & Channel = drop1 & & & \\
\hline \multirow{5}{*}{$\begin{array}{l}\text { Sphyraena barracuda } \\
\text { (great barracuda) }\end{array}$} & No solution & 20 & na & na & Swamp no. $=-0.460^{*}$ & 20 & 0.426 & 0.378 \\
\hline & Canopy = drop1 & & & & Atlantic $=0.238$ & & & \\
\hline & Visible = drop2 & & & & Mang. area $=-0.307$ & & & \\
\hline & Depth $=$ drop3 & & & & Channel = drop1 & & & \\
\hline & & & & & Benthic SDI = drop2 & & & \\
\hline \multirow{3}{*}{$\begin{array}{l}\text { Total fish density } \\
\text { (excluding ACE) }\end{array}$} & Depth $=-0.643^{* *}$ & 22 & 0.298 & 0.019 & Mang. area $=-0.694^{* * *}$ & 22 & 0.481 & 0.291 \\
\hline & Visible $=-0.455^{*}$ & & & & Cont. area $=$ drop 1 & & & \\
\hline & Canopy = drop 1 & & & & Atlantic $=$ drop 2 & & & \\
\hline \multicolumn{9}{|l|}{ Juvenile fish diversity } \\
\hline \multirow[t]{3}{*}{ Shannon evenness index } & $\begin{aligned} \text { Canopy } & =-0.503^{*} \\
\text { Depth } & =-0.293\end{aligned}$ & 22 & 0.169 & 0.313 & $\begin{array}{c}\text { No solution } \\
\text { Swamp no. = drop1 }\end{array}$ & 22 & na & na \\
\hline & Visible = drop1 & & & & Island $\mathrm{p} / \mathrm{a}=$ drop2 & & & \\
\hline & & & & & $\begin{array}{l}\text { Channel }=\text { drop3 } \\
\text { Atlantic }=\text { drop4 }\end{array}$ & & & \\
\hline \multirow[t]{4}{*}{ Rarefied species density } & No solution & 22 & na & na & Seag. area $=0.365^{*}$ & 22 & 0.220 & 0.350 \\
\hline & Canopy = drop 1 & & & & Channel = 0.291 & & & \\
\hline & Depth = drop2 & & & & Atlantic $=0.238$ & & & \\
\hline & Visible $=$ drop 3 & & & & Island $\mathrm{p} / \mathrm{a}=$ drop 1 & & & \\
\hline
\end{tabular}


ple regression model solutions were unique for each species. For example, Atherinid juvenile density was greatest along the margins of islands distant from the Atlantic Ocean $10 \mathrm{~m}$ isobath and surrounded by lowdiversity benthic habitat (likely barren habitat, since there was no univariate relationship between juvenile Atherinid density and either seagrass or hardbottom cover). Juvenile Engraulid density showed a positive relationship with the distance to the Gulf of Mexico $10 \mathrm{~m}$ isobath, while juvenile $L$. griseus occurred in greater density with increasing distance from the Gulf of Mexico and at islands with large perimeter area ratios. A. rhomboidalis juvenile density was negatively associated with benthic habitat diversity, as these fish were more common at sites with extensive, continuous seagrass beds surrounding clustered mangrove islands. Finally, S. barracuda juveniles occurred in greater density near large, isolated mangrove islands, nearer the Atlantic Ocean $10 \mathrm{~m}$ isobath.

\section{Juvenile fish diversity and landscape characteristics}

There was no statistical relationship between juvenile fish species' Shannon evenness index and landscape characteristics (Table 3). Rarefied species density, however, was positively correlated to the proportion of seagrass habitat within $1 \mathrm{~km}$, accounting for $22.0 \%$ of the variability in species density.

\section{DISCUSSION}

Mangroves, often assumed to be important nursery habitat for juvenile fishes of both commercial and ecological importance in the Western Atlantic (Heald \& Odum 1970, Faunce \& Serafy 2006), display high variability in juvenile fish density and diversity. In the GWHNWR, fish survey data gave greater weight to juvenile density regression models incorporating landscape characteristics than those that incorporated siteaveraged microhabitat characteristics. Patterns of juvenile fish diversity were only weakly related to site and landscape characteristics. These results have important implications for (1) the design and interpretation of experiments that address the role of mangroves as nursery habitat, and (2) the development of habitat-based fisheries management and conservation efforts.

The great variability in juvenile fish density among mangrove sites in the refuge suggests that the value of mangroves as nursery habitat for any given species covers a continuous range from poor to excellent quality at multiple spatial scales. Yet, the spatial scale of marine ecological experimental design is commonly constrained by practical considerations and, particu- larly in field experiments, by our human sensory perspective. Research of organism-habitat associations is often scaled down to consider species microhabitat utilization (1 to 10s meters: Eggleston 1995, Dahlgren \& Eggleston 2001, Laegdsgaard \& Johnson 2001, Ellis \& Bell 2004, Darcy \& Eggleston 2005), as these characteristics are viewed as directly influencing recruitment, growth and survival. For example, most studies investigating juvenile fish habitat selection and mortality in mangrove habitat have focused on microhabitat features such as water depth (Laegdsgaard \& Johnson 2001, Cocheret de la Morinière et al. 2004, Ellis \& Bell 2004), light availability (Cocheret de la Morinière et al. 2004, Ellis \& Bell 2004), prop-root density or complexity (Laegdsgaard \& Johnson 2001, Cocheret de la Morinière et al. 2004, Faunce et al. 2004), and prop-root fouling (Laegdsgaard \& Johnson 2001, Serafy et al. 2003, Cocheret de la Morinière et al. 2004). While these microhabitat features can influence the spatial distribution of juvenile fish during daily foraging and resting behaviors, it is unknown whether the importance of these features can be scaled up to explain or predict patterns of fish population density among mangrove islands. It is only known that there is great variability in mangrove habitat use among fish species (Mullin 1995), and very few studies have considered the spatial scaling of fish-mangrove relationships (see review by Faunce \& Serafy 2006).

In the GWHNWR we considered 3 microhabitat characteristics, but we documented these traits at the slightly larger scale of a site average (10s to $100 \mathrm{~s} \mathrm{~m}$ ). This scale represents the finest spatial grain at which species-habitat associations could be defined via rapid fish and fish habitat surveys for conservation and management purposes over a broad regional extent, such as the Florida Keys. When we considered fish and mangrove habitat data as site averages, juvenile fish density of few species correlated with water depth (Gerridae, Anisotremus virginicus and Lutjanus griseus) or distance visible into prop-roots (L. griseus), and none correlated with mangrove canopy height. However, 2 species' juvenile fish density exhibited strong correlation (adjusted $\mathrm{R}^{2}>0.5$ ) with landscape characteristics, while another 2 species exhibited a moderate $\left(0.3<\right.$ adjusted $\left.\mathrm{R}^{2}<0.5\right)$ correlation. Indeed, most species' densities more strongly correlated with landscape (5 of 9 species) than site (2 of 9 species) characteristics. Although these correlations cannot be directly interpreted as causation, they do allow us to rephrase our initial questions as hypotheses for future testing: $\left(H_{1}\right)$ landscape characteristics serve as useful indicators of juvenile fish population and community structure; and $\left(\mathrm{H}_{2}\right)$ landscape metrics increase statistical models' ability to describe population and community variability. 
Past research investigating the nursery role of mangroves at large spatial scales has commonly compared population density or abundance data within binary or categorical habitat units, such as presence versus absence of mangrove habitat (Nagelkerken et al. 2002, Dorenbosch et al. 2004), or mangrove versus seagrass or reef habitat (Chittaro et al. 2005). For organisms that disperse broadly and experience one or more ontogenetic habitat shifts, however, landscape characteristics, such as the relative abundance and connectivity of different habitat types at scales larger than the organisms' daily movement patterns, may influence local population density and diversity as strongly as site characteristics (Rose 2000). If landscape context is important, than binary presence/absence style treatment of mangroves would represent too coarse a scale (e.g. all mangroves treated as homogeneous) to evaluate their role as nursery habitat because it could inflate the variability around the population response means by potentially grouping mangroves that do play a nursery role with those that do not. For example, although numerical data are not published, great variability is observed in Chittaro et al.'s (2005) figures for several mangrove sites (and other habitat types). Experimental evaluation of a given mangrove patch's role as nursery habitat must take into account individual species ecology and not group all mangrove habitat together as a single class because (1) juvenile density is highly variable among mangrove patches, (2) the spatial distribution of high and low juvenile density is unique for each species, (3) some species exhibit density-landscape correlations, and (4) the relationships between juvenile fish density and landscapes are often significant only as multivariate responses. Grouping all mangrove habitat into a single class, particularly in cases where only a small proportion of the mangroves may actually serve as high-quality nursery habitat, could mask any significant nursery effect in field observational or experimental studies. Mangrove nursery studies have been slow to recognize species-habitat relationships as complex, multivariate and multi-scale. Yet, the few studies to explicitly consider multi-scale data have provided valuable insights into the dual influence of initial recruitment and behavior on fish distribution patterns (e.g. Christensen et al. 2003, Kendall et al. 2003). Further study of marine nursery habitats, conducted in conjunction with research into the landscape ecology of juvenile fish, should improve our ability to characterize nursery habitat quality.

The same observations described above (e.g. highly variable fish density and diversity, with each species' response correlating with a unique suite of site and landscape characteristics) have implications for marine conservation and management. Research focused on developing conservation strategies often treat all habi- tat of a given type as homogeneous and are developed to protect a fixed proportion of different habitat types. For example, Leslie et al. (2003) recommended a 'simulating annealing approach' to marine reserve network design based upon their analyses of the Florida Keys using the same benthic habitat data and the same spatial scale $(1 \mathrm{~km})$ that we employed in the present study. Their approach builds reserve networks by selecting individual habitat patches until a predefined percentage of each habitat type is included, while minimizing reserve area and perimeter to facilitate community acceptance and logistic oversight of the reserve (Leslie et al. 2003). While treating all mangroves as equal may not be a problem if the majority of mangroves are targeted for conservation, if only a small percentage of the mangrove habitat is to be protected (Leslie et al. 2003 consider 10 to $30 \%$ habitat protection), then alternative research designs, all protecting the same amount of mangrove habitat, could have very different conservation benefits for different species.

A common conservation practice is to regionally protect a diverse range of habitat types (e.g. seagrass, mangroves, and patch reefs over $10 \mathrm{~s}$ to $100 \mathrm{~s} \mathrm{~km}$ ) as a means to protect regional species diversity. We did not find any association between benthic habitat diversity (Shannon diversity index for benthic habitat within a $1 \mathrm{~km}$ radius) surrounding a mangrove site and juvenile fish diversity within mangrove habitats of the refuge. Instead, a high proportion of seagrass within the same radius was associated with high rarefied species density. However if, as suggested by the present study, the distribution of every species is unique in relation to landscape characteristics, this conclusion adds another dimension to our assessment of habitat diversity. Instead of simply accumulating patches of a given habitat type, it would become important to select patches that also represent the diversity of landscape characteristics.

Although the present study did not identify a single or small suite of habitat characteristics that might serve as an indicator or surrogate for aiding in reserve site selection for all species, our research does support the conclusion that mapped landscape characteristics can provide useful insight into individual juvenile fish species distribution and abundance patterns. Also, the inclusion of simple metrics that accounted for unique features of marine organisms' life histories (e.g. distance to Gulf of Mexico for species believed to spawn in Gulf waters or distance from channels as potential dispersal corridors) was important for several species. That such mapped habitat data and simple life history knowledge could be used to construct regression models explaining a significant proportion of variability in juvenile fish population density is promising, in that the technology for mapping benthic, terrestrial, and hydrographic landscape features are increasingly ac- 
cessible and affordable. Several recent publications have suggested alternate approaches to species conservation and management that could effectively utilize these data in multi-species, multi-scale, organismbased approaches (rather than simpler habitat patch-based approaches) that seem advisable given our results. For example, Rose (2000) argues for the importance and feasibility of uncovering sources of variability in marine populations, and he describes several successful examples of integrating individual-based models, life history theory, and multidisciplinary studies into conservation planning. Fischer et al. (2004) describe contour mapping (visually similar to topographic maps) as a means to intuitively represent habitat quality at multiple, continuous scales. Contour maps could make excellent use of multivariate regression models to map predicted species distribution to (1) aid in the identification of potential population density or diversity hot spots for each species based on multivariate criteria, (2) evaluate the relative benefits of alternative reserve designs to each species and (3) identify gradients in habitat quality that would aid in the development of stratified sampling design.

Acknowledgements. This project was funded through a Challenge Cost-Share Agreement between the Oceans Conservancy and U.S. Fish \& Wildlife Service (contracts 1448-4018199-6 and 1448-40181-00-6143 to D.B.E.), the National Fish and Wildlife Foundation (contract 2004-0011-023 to D.B.E.) and a National Science Foundation Graduate Research Fellowship (DGE-0237090 to C.A.D.). The Fund for Sustainable Fisheries, North Carolina State University, and the PADI Foundation's Project AWARE provided supplemental funding. We thank J. Sobel for facilitating the research funding and his enthusiastic administration of this project, A. Gude (U.S. Fish \& Wildlife Service) for logistic support and Captain L. White for initial field reconnaissance. We thank the following people for their expert fieldwork: M. Darcy, D. Nadeau, D. Parsons, G. Plaia, N. Reyns and S. Searcy. This project was conducted in full compliance of federal and state legislation.

\section{LITERATURE CITED}

Akaike H (1973) Information theory and the extension of the maximum likelihood principle. In: Petrov BN, Caski F (eds) Proc 2nd Int Symp Information Theory. Akademiai Kiado, Budapest, p 267-281

Beck MW, Heck KL Jr, Able KW, Childers DL and others (2001) The identification, conservation, and management of estuarine and marine nurseries for fish and invertebrates. Bioscience 51:633-641

Burnham KP, Anderson DR (2002) Model selection and multimodel inference: a practical information theoretic approach, 2nd edn. Springer, New York

Chittaro PM (2002) Species-area relationships for coral reef fish assemblages of St. Croix, US Virgin Islands. Mar Ecol Prog Ser 233:253-261

> Chittaro PM, Usseglio P, Sale PF (2005) Variation in fish density, assemblage composition and relative rates of predation among mangrove, seagrass and coral reef habitats. Environ Biol Fishes 72:175-187
Christensen JD, Jeffrey CFG, Caldow C, Monaco ME, Kendall MS, Appeldoorn RS (2003) Cross-shelf habitat utilization patterns of reef fishes in southwestern Puerto Rico. Gulf Caribb Res 14:9-27

Cocheret de la Morinière E, Pollux BJA, Nagelkerken I, van der Velde G (2002) Post-settlement life cycle migration patterns and habitat preference of coral reef fish that use seagrass and mangrove habitats as nurseries. Estuar Coast Shelf Sci 55:309-321

Cocheret de la Morinière E, Nagelkerken I, van der Meij H, van der Velde G (2004) What attracts juvenile coral reef fish to mangroves: habitat complexity or shade? Mar Biol 144:139-145

> Collinge SK (2001) Spatial ecology and biological conservation. Biol Conserv 100:1-2

$>$ Dahlgren CP, Eggleston DB (2001) Spatio-temporal variability in abundance, size and microhabitat associations of early juvenile Nassau grouper Epinephelus striatus in an off-reef nursery system. Mar Ecol Prog Ser 217: $145-156$

Darcy MC, Eggleston DB (2005) Do habitat corridors influence animal dispersal and colonization in estuarine systems? Landscape Ecol 20:841-855

Doak DF, Mills LS (1994) A useful role for theory in conservation. Ecology 75:615-626

Dorenbosch M, van Riel MC, Nagelkerken I, van der Velde G (2004) The relationship of reef fish densities to the proximity of mangrove and seagrass nurseries. Estuar Coast Shelf Sci 60:37-48

Eggleston DB (1995) Recruitment in Nassau grouper Epinephelus striatus: post-settlement abundance, microhabitat features, and ontogenetic habitat shifts. Mar Ecol Prog Ser 124:9-22

Eggleston DB, Dahlgren CP (2001) Distribution and abundance of Caribbean spiny lobsters in the Key West National Wildlife Refuge: relationship to habitat features and impact of an intensive recreational fishery. Mar Freshw Res 52:1567-1576

> Eggleston DB, Etherington LL, Ellis WE (1998) Organism response to habitat patchiness: species and habitat dependent recruitment of decapod crustaceans. J Exp Mar Biol Ecol 223:111-132

Eggleston DB, Ellis WE, Etherington LL, Dahlgren CP, Posey $\mathrm{MH}$ (1999) Organism responses to habitat fragmentation and diversity: habitat colonization by estuarine macrofauna. J Exp Mar Biol Ecol 236:107-132

Eggleston DB, Bell GW, Johnson EG, Kellison GT (2004a) Fish and spiny lobster density, size structure, and fish diversity within multiple back reef habitats of Great White Heron National Wildlife Refuge, USA. Final report in partial fulfillment of a challenge cost-share agreement between the Center for Marine Conservation and US Fish and Wildlife Service of contracts 1448-40181-99-6 and 144840181-00-6143. North Carolina State University, Raleigh, $\mathrm{NC}$

Eggleston DB, Dahlgren CP, Johnson EG (2004b) Fish density, diversity, and size-structure within multiple back reef habitats of Key West National Wildlife Refuge, USA. Bull Mar Sci 75:175-204

Eggleston DB, Searcy SP, Plaia G, Reyns NB (2004c) Ingress of postlarval spiny lobster and larval fish to the Great White Heron National Wildlife Refuge: an initial assessment of Atlantic Ocean versus Gulf Stream sources. Final report in partial fulfillment of a challenge cost-share agreement between the Oceans Conservancy and US Fish and Wildlife Service for contracts 1448-40181-99-6 and 1448-40181-00-6143. Department of Marine, Earth, and 
Atmospheric Sciences, North Carolina State University, Raleigh, NC

Ellis WL, Bell SS (2004) Conditional use of mangrove habitats by fishes: depth as a cue to avoid predators. Estuaries 27: 966-967

Faunce CH, Serafy JE (2006) Mangroves as fish habitat: 50 years of field studies. Mar Ecol Prog Ser 318:1-18

Faunce C, Serafy J, Jerome L (2004) Density-habitat relationships of mangrove creek fishes within the southeastern saline Everglades (USA), with reference to managed freshwater releases. Wetlands Ecol Manag 12:377-394

Fischer J, Lindenmayer DB, Fazey I (2004) Appreciating ecological complexity: habitat contours as a conceptual landscape model. Conserv Biol 18:1245-1253

Florida Fish and Wildlife Conservation Commission (2004) Florida vegetation and land cover - 2003. State of Florida, Tallahassee, FL

Florida Marine Research Institute (1998) Coastal and marine resource assessment: Florida Keys benthic habitats. National Oceanographic and Atmospheric Administration, St. Petersburg, FL

Froese R, Pauly D (2000) FishBase 2000: concepts, design and data sources. International Center for Living Aquatic Resources Management, Los Baños, Laguna

Gillanders BM, Able KW, Brown JA, Eggleston DB, Sheridan PF (2003) Evidence of connectivity between juvenile and adult habitats for mobile marine fauna: an important component of nurseries. Mar Ecol Prog Ser 247:281-295

Gotelli NJ, Colwell RK (2001) Quantifying biodiversity: procedures and pitfalls in the measurement and comparison of species richness. Ecol Lett 4:379-391

Halpern BS (2004) Are mangroves a limiting resource for two coral reef fishes? Mar Ecol Prog Ser 272:93-98

Heald EJ, Odum WE (1970) The contribution of mangrove swamps to Florida fisheries. Proc Gulf Caribb Fish Inst 22: 130-135

> Hovel KA, Lipcius RN (2002) Effects of seagrass habitat fragmentation on juvenile blue crab survival and abundance. J Exp Mar Biol Ecol 271:75-98

Kendall MS, Christensen JD, Hillis-Starr Z (2003) Multi-scale data used to analyze the spatial distribution of French grunts, Haemulon flavolineatum, relative to hard and soft bottom in a benthic landscape. Environ Biol Fishes 66: $19-26$

Laegdsgaard P, Johnson C (2001) Why do juvenile fish utilise mangrove habitats? J Exp Mar Biol Ecol 257:229-253

Legendre P, Legendre L (1998) Numerical ecology. Elsevier, New York

Leslie H, Ruckelhaus M, Ball IR, Andelman SJ, Possingham HP (2003) Using siting algorithms in the design of marine reserve networks. Ecol Appl 13:185-198

Editorial responsibility: Kenneth Heck,

Dauphin Island, Alabama, USA
McCune B, Grace JB (2002) Ecological analysis of communities. MjM Software Design, Gleneden Beach, OR

Mullin SJ (1995) Estuarine fish populations among red mangrove prop-roots of small overwash islands. Wetlands 15: 324-329

Mumby PJ, Edwards AJ, Arias-Gonzalez JE, Lindeman KC and others (2004) Mangroves enhance the biomass of coral reef fish communities in the Caribbean. Nature 427 : $533-536$

Nagelkerken I, van der Velde G (2002) Do non-estuarine mangroves harbour higher densities of juvenile fish than adjacent shallow-water and coral reef habitats in Curaçao (Netherlands Antilles)? Mar Ecol Prog Ser 245:191-204

> Nagelkerken I, van der Velde G (2004) A comparison of fish communities of subtidal seagrass beds and sandy seabeds in 13 marine embayments of a Caribbean Island, based on size, families, size distribution and functional groups. J Sea Res 52:127-147

Nagelkerken I, Roberts CM, van der Velde G, Dorenbosch M, van Riel MC, Cocheret de la Morinière E, Nienhuis $\mathrm{PH}$ (2002) How important are mangroves and seagrass beds for coral-reef fish? The nursery hypothesis tested on an island scale. Mar Ecol Prog Ser 244:299-305

Poiani KA, Richter BD, Anderson MG, Richter HE (2000) Biodiversity conservation at multiple scales: functional sites, landscapes, and networks. Bioscience 50:133-146

Rooker JR, Dennis GD (1991) Diel, lunar, and seasonal changes in a mangrove fish assemblage off southwestern Puerto Rico. Bull Mar Sci 49:684-698

Rose KA (2000) Why are quantitative relationships between environmental quality and fish populations so elusive? Ecol Appl 10:367-385

Sanders HL (1968) Marine benthic diversity: a comparative study. Am Nat 102:243-282

Serafy JE, Faunce CH, Lorenz JJ (2003) Mangrove shoreline fishes of Biscayne Bay, Florida. Bull Mar Sci 72:161-180

Sheaves M (2005) Nature and consequences of biological connectivity in mangrove systems. Mar Ecol Prog Ser 302: 293-305

Sheridan PF, Hays CG (2003) Are mangroves nursery habitat for transient fishes and decapods? Wetlands 23:449-458

Smith TJ III, Whelan KRT (2006) Development of allometric relations for three mangrove species in South Florida for use in the Greater Everglades Ecosystem restoration. Wetlands Ecol Manag 14:409-419

Washington HG (1984) Diversity, biotic, and similarity indices: a review with special relevance to aquatic ecosystems. Water Res 18:653-694

Watling JI, Donnelly MA (2006) Fragments as islands: a synthesis of faunal responses to habitat patchiness. Conserv Biol 20:1016-1025

Submitted: February 20, 2007; Accepted: January 25, 2008 Proofs received from author(s): June 2, 2008 